\title{
Pengaruh Ukuran Perusahaan, Profitabilitas, Leverage, Likuiditas dan Sales Growth terhadap Kebijakan Dividen (Studi Empiris pada Perusahaan LQ45 Yang Terdaftar di Bursa Efek Indonesia Tahun 2016-2018)
}

\author{
Arifa Nur Azizah ${ }^{1 *}$, Riana R Dewi ${ }^{2}$, Purnama Siddi $^{3}$ \\ ${ }^{1,2,3}$ Universitas Islam Batik, Jl. KH. Agus Salim No. 10, Surakarta, Indonesia \\ "Correspondence email: arifanura@gmail.com
}

\begin{abstract}
Abstrak. Penelitian ini bertujuan untuk menguji dan menganalisis pengaruh ukuran perusahaan, profitabilitas, leverage, likuiditas dan sales growth terhadap kebijakan dividen pada Perusahaan LQ45 yang terdaftar di Bursa Efek Indonesia tahun 2016-2018. Populasi dari penelitian ini adalah seluruh Perusahaan yang tergolong indeks LQ45 yang terdaftar di BEI tahun 2016-2018. Penggunaan sampel pada penelitian menggunakan Purposive Sampling dengan kriteria tertentu sehingga diperoleh 66 sampel data untuk diteliti. Data yang digunakan adalah data sekunder yang bersumber dari laporan keuangan. Penelitian ini menggunakan metode Uji Analisis Regresi Linear Berganda. Dari uji tersebut dapat diketaui bahwa Ukuran Perusahaan, Profitabilitas dan Leverage berpengaruh terhadap Kebijakan Dividen. Sedangkan Likuiditas dan Sales growth tidak berpengaruh terhadap Kebijakan Dividen pada Perusahaan LQ45 tahun 2016-2018.
\end{abstract}

Kata kunci : Ukuran Perusahaan; Profitabilitas; Leverage; Kebijakan Dividen

Abstract. This study aims to examine and analyze the effect of company size, profitability, leverage, liquidity and sales growth on dividend policy on LQ45 companies listed on the Indonesia Stock Exchange in 2016-2018. The population of this study is all companies belonging to the LQ45 index listed on the Indonesia Stock Exchange in 2016-2018. The use of samples in research using Purposive Sampling with certain criteria in order to obtain 66 data samples to be studied. The data used are secondary data sourced from financial statements. This research uses Multiple Linear Regression Analysis Test method. From these tests it can be seen that Company Size, Profitability and Leverage affect Dividend Policy. While Liquidity and Sales growth does not affect the Dividend Policy in LQ45 Companies in 2016-2018.

Keywords : Firm Size; Profitability; Leverage; Dividend Policy

\section{PENDAHULUAN}

Investasi adalah kegiatan menanamkan sejumlah dana pada saat ini dengan tujuan untuk memperoleh return atau keuntungan di masa depan. Investasi dapat dilakukan pada aset nyata dan aset finansial. Pihak yang melakukan aktivitas investasi disebut dengan investor (Tandelilin, 2010). Salah satu bentuk investasi di pasar modal adalah saham. Tujuan utama seorang investor saham dalam menginvestasikan dananya adalah untuk memperoleh pendapatan (return) yang dapat berupa pendapatan dividen (dividen yield) maupun pendapatan dari selisih harga jual saham terhadap harga belinya (capital gains).

Menurut Rudianto (2012), menyatakan dividen adalah bagian dari laba yang diperoleh perusahaan dan diberikan oleh perusahaan kepada pemegang saham sebagai imbalan atas kesediaannya menanamkan hartanya didalam perusahaan. Keputusan untuk menentukan berapa banyak dividen yang harus dibagikan kepada para investor disebut kebijakan deviden (dividend policy). Atmaja (2008) menyatakan kebijakan dividen berkaitan dengan keputusan apakah perusahaan akan membagikan dividen kepada para pemegang saham atau menahan laba untuk diinvestasikan kembali pada proyek-proyek yang menguntungkan guna meningkatkan pertumbuhan perusahaan.

Menurut Sutrisno (2013) ada beberapa faktor yang mempengaruhi besar kecilnya dividen yang akan dibayarkan oleh perusahaan kepada pemegang saham yaitu posisi solvabilitas perusahaan, posisi likuiditas perusahaan, kebutuhan untuk melunasi hutang untuk rencana perluasan perusahaan dan kesempatan investasi. Dalam penelitian ini akan digunakan faktor yang mempengaruhi kebijakan dividen adalah ukuran perusahaan, profitabilitas, leverage, likuiditas dan sales growth (pertumbuhan penjualan).

Ukuran perusahaan yang dapat diartikan sebagai besar kecilnya perusahaan dilihat dari besarnya nilai equity, nilai perusahaan, ataupun hasil nilai total aktiva dari suatu perusahaan (Riyanto, 2011). Penelitian yang dilakukan oleh Lestari (2017) dan Yusuf (2019) menyatakan bahwa ukuran perusahaan memiliki pengaruh positif terhadap kebijakan dividen, sedangkan dalam penelitian Ali, Mohamad, \& Baharuddin (2018) menyatakan ukuran perusahaan memiliki pengaruh negatif terhadap kebijakan dividen. Berbeda dengan penelitian Paramita (2015) menyatakan bahwa ukuran perusahaan tidak berpengaruh terhadap kebijakan dividen. 
Arifa Nur Azizah et al, Pengaruh Ukuran Perusahaan, Profitabilitas, Leverage, Likuiditas dan Sales Growth terhadap Kebijakan Dividen (Studi Empiris pada Perusahaan LQ45 Yang Terdaftar di Bursa Efek Indonesia Tahun 2016-2018)

Rasio profitabilitas digunakan untuk mengukur kemampuan perusahaan dalam menghasilkan laba dengan semua aktiva atau aset yang dimiliki oleh perusahaan, return on asset atau yang sering disingkat ROA merupakan hasil pembagian antara laba bersih dengan total aktiva atau aset yang dimiliki perusahaan (Sutrisno, 2013). Penelitian Lestari (2017) dan Ginting (2018) menyatakan bahwa profitabilitas (ROA) memiliki pengaruh positif terhadap kebijakan dividen. Berbeda dengan penelitian Sari \& Sudjarni (2015) dan Lin, Thaker, \& Khaliq (2018) menyatakan bahwa profitabilitas (ROA) tidak berpengaruh terhadap kebijakan dividen.

Leverage mencerminkan perusahaan dalam memenuhi seluruh kewajibannya yang ditunjukkan oleh beberapa bagian modal sendiri yang digunakan untuk membayar hutang (Rodoni \& Ali, 2010). Penelitian Sari \& Sudjarni (2015) menyatakan bahwa leverage memiliki pengaruh negatif terhadap kebijakan dividen, sejalan dengan penelitian yang dilakukan oleh Yudiana \& Yadnyana (2016) dan Yusuf (2019). Berbeda dengan penelitian Lestari (2017) dan Ginting (2018) yang menyatakan leverage tidak berpengaruh terhadap kebijkan dividen.

Rasio likuiditas merupakan rasio yang menggambarkan kemampuan perusahaan memenuhi kewajiban (utang) jangka pendek (Kasmir, 2012). Penelitian Sari \& Sudjarni (2015) menyatakan bahwa likuiditas memiliki pengaruh positif terhadap kebijakan dividen, sejalan dengan penelitian yang dilakukan oleh Iswara (2017) dan Hadila Hapsari (2018). Berbeda dengan penelitian Ginting (2018) dan Lin et al (2018) yang menyatakan likuiditas tidak berpengaruh terhadap kebijakan dividen.

Sales Growth dapat dilihat dari pertumbuhan penjualan perusahaan dari tahun ke tahun. Menurut Kasmir (2012), rasio pertumbuhan merupakan rasio yang menggambarkan kemampuan perusahaan dalam mempertahakan posisi ekonominya di tengah pertumbuhan perekonomian dan sektor usahanya. Penelitian yang dilakukan oleh Prastika \& Pinem (2016) menyatakan bahwa sales growth memiliki pengaruh negatif terhadap kebijakan dividen. Berbeda dengan penelitian Hantono, Sari, Felicya, Hartono, \& Daeri (2019) menyatakan bahwa pertumbuhan penjualan tidak berpengaruh terhadap kebijakan dividen.

Berdasarkan latar belakang yang telah diuraikan sebelumnya, maka rumusan masalah penelitian ini: apakah ukuran perusahaan, profitabilitas, leverage, likuiditas dan sales growth berpengaruh terhadap kebijakan dividen?. Penelitian ini bertujuan untuk menguji dan menganalisis pengaruh ukuran perusahaan, profitabilitas, leverage, likuiditas dan sales growth terhadap kebijakan dividen.

\section{METODE}

Jenis penelitian ini adalah kuantitatif dan sumber data sekunder yang diperoleh secara tidak langsung dari Perusahaan. Data laporan keuangan Perusahaan LQ45 di Bursa Efek Indonesia tahun 2016-2018 yang dapat diakses di situs www.idx.co.id. Penelitian ini menggunakan metode analisis regresi linier berganda.

Populasi yang digunakan meliputi seluruh perusahaan yang tergolong indeks LQ45 yang terdaftar di Bursa Efek Indonesia pada tahun 2016-2018. Pemilihan sampel dilakukan dengan teknik purposive sampling, adapun kriteria yang digunakan adalah:

1. Perusahaan yang konsisten masuk dalam indeks LQ45 periode 2016-2018

2. Perusahaan LQ45 yang menyajikan laporan keuangan menggunakan mata uang rupiah (Rp)

3. Perusahaan LQ45 yang membagikan dividen secara konsisten selama tahun penelitian 2016-2018

4. Perusahaan LQ45 yang mengalami tingkat pertumbuhan positif tahun 2016-2018.

Variabel dependen dalam penelitian ini adalah kebijakan dividen yang diukur dengan dividend payout ratio (DPR) dengan rumus dividen dibagi laba bersih setelah pajak.

Variabel independen dalam penelitian ini ada 5 yaitu:

1. Ukuran perusahaan yang dilihat dari total aset dengan rumus logaritma natural dari total aset

2. Profitabilitas yang diaproksikan dengan return on assets (ROA) dengan rumus laba bersih setelah pajak dibagi dengan total aset.

3. Leverage yang diaproksikan dengan debt equity ratio (DER) dengan rumus total hutang dibagi dengan total modal

4. Likuiditas yang diaproksikan dengan current ratio (CR) dengan rumus aset lancar dibagi dengan kewajiban jangka pendek.

5. Sales growth atau pertumbuhan penjualan dengan rumus penjualan dikurangi penjualan tahun sebelumnya dibagi penjualan tahun sebelumnya.

Teknik analisis yang digunakan dalam penelitian ini adalah analisis regresi linier berganda yang diproses menggunakan program SPSS versi 23.

\section{HASIL DAN PEMBAHASAN}

Penelitian ini menggunakan data sekunder berupa laporan keuangan dan laporan tahunan perusahaan yang diperoleh dari www.idx.co.id. (website resmi Bursa Efek Indonesia). Populasi dalam penelitian ini menggunakan seluruh perusahaan yang tergolong indeks LQ45 yang terdaftar di Bursa Efek Indonesia pada tahun 2016-2018. Pemilihan sampel dilakukan dengan teknik purposive sampling, yaitu pemilihan sampel yang didasarkan pada kriteria tertentu. 
Arifa Nur Azizah et al, Pengaruh Ukuran Perusahaan, Profitabilitas, Leverage, Likuiditas dan Sales Growth terhadap Kebijakan Dividen (Studi Empiris pada Perusahaan LQ45 Yang Terdaftar di Bursa Efek Indonesia Tahun 2016-2018)

Tabel 1. Prosedur Pemilihan Sampel

\begin{tabular}{clc}
\hline No & Keterangan & Jumlah \\
\hline 1 & $\begin{array}{l}\text { Perusahaan yang konsisten masuk dalam } \\
\text { indeks LQ45 periode 2016-2018 }\end{array}$ & 33 \\
2 & $\begin{array}{l}\text { Perusahaan LQ45 yang tidak menyajikan } \\
\text { laporan keuangan dengan mata uang rupiah } \\
\text { (Rp) }\end{array}$ & \\
3 & $\begin{array}{l}\text { Perusahaan LQ45 yang tidak konsisten } \\
\text { membagikan dividen periode 2016-2018 }\end{array}$ \\
4 & $\begin{array}{l}\text { Perusahaan LQ45 yang mengalami tingkat } \\
\text { pertumbuhan negatif tahun 2016-2018 }\end{array}$ \\
Jumlah sampel perusahaan \\
Jumlah sampel penelitian 3 tahun x 22
\end{tabular}

Sumber: Data Hasil Penelitian, 2020

Berdasarkan tabel diatas dapat dilihat bahwa jumlah sampel perusahaan LQ45 selama periode 20162018 adalah 22 perusahaan dan jumlah sampel penelitian adalah 66 sampel.

\section{Uji Normalitas}

Tabel 2. Hasil Uji Normalitas

\begin{tabular}{lccc}
\hline & $\begin{array}{c}\text { Undstandardized } \\
\text { residual }\end{array}$ & Standar & Keterangan \\
Asymp. sig & 0,200 & $>0,05$ & $\begin{array}{c}\text { Terdistribusi } \\
\text { normal }\end{array}$ \\
\hline
\end{tabular}

Sumber: Data Hasil Penelitian, 2020

Berdasarkan tabel 2 diatas menunjukkan bahwa nilai Asymp.Sig. (2-tailed) yaitu 0,200 yang nilainya lebih besar dari 0,05 sehingga dapat disimpulkan bahwa data terdistribusi secara normal.

\section{Uji Multikoloniearitas}

Tabel 3. Hasil Uji Multikoloniearitas

\begin{tabular}{cccc}
\hline Variabel & Tolerance & VIF & Kesimpulan \\
\cline { 2 - 2 } Ukuran perusahaan & 0,411 & 2,431 & Tidak terjadi \\
Profitabilitas & 0,591 & 1,692 & Tidak terjadi \\
Leverage & 0,508 & 1,967 & Tidak terjadi \\
Likuiditas & 0,680 & 1,470 & Tidak terjadi \\
Sales growth & 0,475 & 2,106 & Tidak terjadi \\
\hline
\end{tabular}

Sumber: Data Hasil Penelitian, 2020

Dari tabel 3 menunjukkan tidak ada variabel bebas yang memiliki nilai tolerance kurang dari 0,1 atau $10 \%$ dari hasil perhitungan VIF juga menunjukkan tidak ada variabel bebas yang memiliki nilai VIF lebih 10, oleh karena itu dapat disimpulkan bahwa tidak terjadi multikolonieritas antar variabel.

Uji Autokorelasi

Tabel 4. Hasil Uji Autokorelasi

\begin{tabular}{cccc}
\hline & $\begin{array}{c}\text { Undstandardized } \\
\text { residual }\end{array}$ & Standar & Keterangan \\
\cline { 1 - 2 } Asymp.sig & 0,457 & $>0,05$ & $\begin{array}{l}\text { Tidak terjadi } \\
\text { autokorelasi }\end{array}$ \\
\cline { 1 - 2 } & &
\end{tabular}

Berdasarkan tabel pengujian autokorelasi diatas dengan uji run test diketahui nilai Asymp. Sig. (2Tailed) sebesar 0,457 lebih besar dari >0,05, maka dapat disimpulkan bahwa tidak terdapat gejala atau masalah autokorelasi.

Uji Heteroskesdastisitas

Tabel 5. hasil Uji Heteroskesdastisitas

\begin{tabular}{cccc}
\hline Variabel & Sig (2 tailed) & standar & Kesimpulan \\
\cline { 2 - 2 } Ukuran & 0,391 & $>0,05$ & Tidak terjadi \\
perusahaan & 0,910 & $>0,05$ & Tidak terjadi \\
Profitabilitas & 0,079 & $>0,05$ & Tidak terjadi \\
Leverage & 0,365 & $>0,05$ & Tidak terjadi \\
Likuiditas & 0,467 & $>0,05$ & Tidak terjadi \\
Sales growth & &
\end{tabular}

Sumber: Data Hasil Penelitian, 2020

Dari hasil uji heteroskedastisitas pada tabel 5 terlihat bahwa semua variabel independen memilki sig.(2-tailed) lebih dari 0,05. Sehingga dapat disimpulkan bahwa semua variabel independen bebas dari masalah heteroskedastisitas.

Uji Regresi Linear Berganda

Tabel 6. Hasil Uji Regresi Linear Berganda

\begin{tabular}{cc}
\hline Model & B \\
\hline (Constant) & $-1,190$ \\
Ukuran perusahaan & 0,048 \\
Profitabilitas & 1,856 \\
Leverage & $-0,027$ \\
Likuiditas & $-0,016$ \\
Sales growth & 0,021 \\
\hline
\end{tabular}

Sumber: Hasil Data Penelitian, 2020

Berdasarkan tabel diatas, dapat disusun persamaan garis regresi sebagai berikut :

$$
\begin{aligned}
& Y=-1,190+0,048 X 1+1,856 \mathrm{X} 2-0,027 \mathrm{X} 3-0,016 \\
& \mathrm{X} 4+0,021 \mathrm{X} 5
\end{aligned}
$$

Persamaan garis regresi tersebut dapat dijelaskan masing-masing sebagai berikut:

1. Nilai konstanta sebesar $-1,190$ menunjukkan bahwa apabila variabel independen bernilai 0 maka nilai kebijakan dividen sebesar -1,190.

2. $X_{1}$ adalah variabel ukuran perusahaan yang memiliki nilai koefisien regresi sebesar 0,048. Hal ini menunjukkan bahwa setiap ukuran perusahaan naik sebesar 1 akan diikuti dengan kenaikan kebijakan dividen sebesar 0,048 dengan asumsi variabel lain tetap atau sama dengan nol.

3. $\mathrm{X}_{2}$ adalah variabel profitabilitas yang memiliki nilai koefisien regresi sebesar 1,856. Hal ini menunjukkan bahwa setiap profitabilitas naik sebesar 1 akan diikuti dengan kenaikan kebijakan dividen sebesar 1,856 dengan asumsi variabel lain tetap atau sama dengan nol. 
Arifa Nur Azizah et al, Pengaruh Ukuran Perusahaan, Profitabilitas, Leverage, Likuiditas dan Sales Growth terhadap Kebijakan Dividen (Studi Empiris pada Perusahaan LQ45 Yang Terdaftar di Bursa Efek Indonesia Tahun 2016-2018)

4. $\mathrm{X}_{3}$ adalah variabel leverage yang memiliki nilai koefisien regresi sebesar -0,027. Hal ini menunjukkan bahwa setiap leverage naik sebesar 1 akan diikuti dengan penurunan kebijakan dividen sebesar 0,027 dengan asumsi variabel lain tetap atau sama dengan nol.

5. $\mathrm{X}_{4}$ adalah variabel likuiditas yang memiliki nilai koefisien regresi sebesar -0,016. Hal ini menunjukkan bahwa setiap likuiditas naik sebesar 1 akan diikuti dengan penurunan kebijakan dividen sebesar 0,016 dengan asumsi variabel lain tetap atau sama dengan nol.

6. $\mathrm{X}_{5}$ adalah variabel sales growth yang memiliki nilai koefisien regresi sebesar 0,021 . Hal ini menunjukkan bahwa setiap sales growth naik sebesar 1 akan diikuti dengan kenaikan kebijakan dividen sebesar 0,021 dengan asumsi variabel lain tetap atau sama dengan nol.

\section{Uji Kelayakan Model}

Tabel 7. Hasil Uji Kelayakan Model

\begin{tabular}{ccccc}
\hline$F_{\text {hitung }}$ & $\mathrm{F}_{\text {tabel }}$ & Sig. & Standar & Kesimpulan \\
\hline 19,535 & 2,368 & 0,000 & $<0,05$ & Model Layak \\
\hline
\end{tabular}

Sumber: Hasil Data Penelitian, 2020

Uji kelayakan model diatas memperoleh hasil $F_{\text {hitung }}>F_{\text {tabel }}$ yaitu sebesar 19,535 $>2,368$ dan nilai Signifikasi $<0,05$ yaitu sebesar $0,000<0,05$ maka dapat disimpulkan bahwa model memenuhi kelayakan.

Uji Hipotesis

Tabel 8. Hasil Uji Hipotesis

\begin{tabular}{ccccc}
\hline Variabel & $\mathrm{T}_{\text {hitung }}$ & $\mathrm{T}_{\text {tabel }}$ & Sig. & Hasil \\
\cline { 1 - 1 } Ukuran & 2,667 & $>2,000$ & 0,010 & Diterima \\
perusahaan & & & & \\
Profitabilitas & 7,950 & $>2,000$ & 0,000 & Diterima \\
Leverage & $-2,600$ & $>-2,000$ & 0,012 & Diterima \\
Likuiditas & $-0,798$ & $<-2,000$ & 0,428 & Ditolak \\
Sales growth & 0,383 & $<2,000$ & 0,703 & Ditolak \\
\hline
\end{tabular}

Sumber: Data Hasil Penelitian, 2020

Hasil pengujian hipotesis 1 menunjukkan nilai $\mathrm{t}_{\text {hitung }} 2,667>\mathrm{t}_{\text {tabel }} 2,000$ dan signifikansi $0,010<0,05$, sehingga dapat disimpulkan bahwa ukuran perusahaan berpengaruh terhadap kebijakan dividen.

Hasil pengujian hipotesis 2 menunjukkan nilai $t_{\text {hitung }} 7,950>t_{\text {tabel }} 2,000$ dan signifikansi $0,000<0,05$, sehingga dapat disimpulkan bahwa profitabilitas berpengaruh terhadap kebijakan dividen.

Hasil pengujian hipotesis 3 menunjukkan nilai $\mathrm{t}_{\text {hitung }}-2,600>\mathrm{t}_{\text {tabel }}-2,000$ dan signifikansi $0,012<0,05$, sehingga dapat disimpulkan bahwa leverage berpengaruh terhadap kebijakan dividen.

Hasil pengujian hipotesis 4 menunjukkan nilai $\mathrm{t}_{\text {hitung }}-0,798<\mathrm{t}_{\text {tabel }}-2,000$ dan signifikansi $0,428>0,05$, sehingga dapat disimpulkan bahwa likuiditas tidak berpengaruh terhadap kebijakan dividen.

Hasil pengujian hipotesis 5 menunjukkan nilai $t_{\text {hitung }} 0,383<t_{\text {tabel }} 2,000$ dan signifikansi $0,703>0,05$, sehingga dapat disimpulkan bahwa sales growth tidak berpengaruh terhadap kebijakan dividen.

Uji Koefisien Determinasi $\mathrm{R}^{2}$

Tabel 9. Hasil Uji Koefisien Determinasi $\mathrm{R}^{2}$

\begin{tabular}{cc}
\hline Adjusted R Square & Hasil \\
\hline 0,588 & $58,8 \%$ \\
\hline
\end{tabular}

Sumber: Hasil data Penelitian, 2020

Pada tabel 9 terlihat nilai Adjusted $\mathrm{R}$ Square sebesar 0,588 atau sebesar 58,8\%. Hal ini menunjukkan bahwa variasi kebijakan dividen yang dapat dijelaskan oleh variabel ukuran perusahaan, profitabilitas, leverage, likuiditas dan sales growth sebesar 58,8\%, sedangkan sisanya $41,2 \%$ dijelaskan oleh variabel lain diluar model.

\section{Pembahasan \\ Pengaruh ukuran perusahaan terhadap kebijakan dividen}

Berdasarkan hasil pengujian hipotesis 1 menunjukkan bahwa variabel ukuran perusahaan berpengaruh terhadap kebijakan dividen pada perusahaan LQ45 tahun 2016-2018. Artinya besar kecilnya jumlah aset atau ukuran suatu perusahaan akan mempengaruhi besar kecilnya kebijakan dividen. Semakin besar ukuran perusahaan / jumlah aset yang dimiliki perusahaan maka jumlah dividen yang dibayarkan kepada pemegang saham pun akan meningkat, sebaliknya jika semakin kecil ukuran perusahaan / jumlah aset yang dimiliki perusahaan maka jumlah dividen yang dibayarkan kepada pemegang saham pun akan semakin menurun. Hasil pengujian ini sejalan dengan penelitian yang dilakukan oleh Lestari (2017), Ali et al (2018) dan Yusuf (2019) menyatakan bahwa ukuran perusahaan berpengaruh terhadap kebijakan dividen, namun berbeda dengan penelitian Iswara (2017) bahwa ukuran perusahaan tidak berpengaruh terhadap kebijakan dividen.

\section{Pengaruh profitabilitas terhadap kebijakan dividen}

Berdasarkan hasil pengujian hipotesis 2 menunjukkan bahwa variabel profitabilitas yang diukur menggunakan return on assets (ROA) berpengaruh terhadap kebijakan dividen pada perusahaan LQ45 tahun 2016-2018. Artinya besar kecilnya laba perusahaan akan mempengaruhi besar kecilnya pembagian dividen. Perusahaan yang memperoleh laba cenderung membagikan dividen kepada pemegang saham. Semakin besar jumlah laba yang dihasilkan maka jumlah dividen yang dibayarkan kepada pemegang saham pun akan meningkat, sebaliknya jika semakin kecil jumlah laba yang dihasilkan maka jumlah dividen yang dibayarkan kepada pemegang saham pun akan semakin kecil. Hasil 
Arifa Nur Azizah et al, Pengaruh Ukuran Perusahaan, Profitabilitas, Leverage, Likuiditas dan Sales Growth terhadap Kebijakan Dividen (Studi Empiris pada Perusahaan LQ45 Yang Terdaftar di Bursa Efek Indonesia Tahun 2016-2018)

pengujian ini sejalan dengan penelitian yang dilakukan oleh Lestari (2017), Ginting (2018) dan Ali et al (2018) menyatakan bahwa profitabilitas yang diukur dengan return on asset (ROA) berpengaruh terhadap kebijakan dividen, namun berbeda dengan penelitian Hantono et al (2019) bahwa profitabilitas yang diukur dengan return on asset (ROA) tidak berpengaruh terhadap kebijakan dividen.

\section{Pengaruh leverage terhadap kebijakan dividen}

Berdasarkan hasil pengujian hipotesis 3 menunjukkan bahwa variabel leverage berpengaruh terhadap kebijakan dividen pada perusahaan LQ45 tahun 2016-2018. Artinya besar kecilnya leverage akan mempengaruhi besar kecilnya kebijakan dividen. Perusahaan yang memiliki tingkat hutang yang tinggi menyebabkan pihak manajemen akan memprioritaskan pelunasan kewajiban terlebih dahulu sebelum membagikan dividen kepada pemegang saham. Sehingga semakin tinggi leverage perusahaan maka kebijakan dividennya akan semakin rendah, sebaliknya jika semakin rendah leverage perusahaan maka kebijakan dividenya akan semakin tinggi. Hasil pengujian ini sejalan dengan penelitian yang dilakukan oleh Sari \& Surjani (2015) dan Yusuf (2019) bahwa leverage yang diukur dengan debt equity ratio (DER) berpengaruh terhadap kebijakan dividen, namun berbeda dengan penelitian Hantono et al (2019) bahwa leverage yang diukur dengan debt equity ratio (DER) tidak berpengaruh terhadap kebijakan dividen.

\section{Pengaruh likuiditas terhadap kebijakan dividen}

Berdasarkan hasil pengujian hipotesis 4 menunjukkan bahwa variabel likuiditas yang diukur dengan current ratio (CR) tidak berpengaruh terhadap kebijakan dividen pada perusahaan LQ45 tahun 20162018. Artinya besar kecilnya likuiditas perusahaan tidak mempengaruhi kebijakan dividen. Perusahaan yang likuid tidak menjadi tolok ukur perusahaan akan membagikan dividen, dikarenakan aset lancar yang dimiliki oleh perusahaan lebih diutamakan untuk memenuhi kewajiban lancarnya dan untuk tujuan lain yang berkaitan dengan operasional perusahaan. Hasil pengujian ini sejalan dengan penelitian yang dilakukan oleh Lin et al (2018) bahwa likuiditas yang diukur dengan current ratio (CR) tidak berpengaruh terhadap kebijakan dividen, namun berbeda dengan penelitian Hadila \& Hapsari (2018) bahwa likuiditas yang diukur dengan current ratio (CR) berpengaruh terhadap kebijakan dividen.

\section{Pengaruh sales growth terhadap kebijakan dividen}

Berdasarkan hasil pengujian hipotesis 5 menunjukkan bahwa variabel sales growth tidak berpengaruh terhadap kebijakan dividen pada perusahaan LQ45 tahun 2016-2018. Artinya besar kecilnya tingkat pertumbuhan penjualan suatu perusahaan tidak mempengaruhi kebijakan dividen. Perusahaan dengan penjualan yang besar dan akses pasar yang baik akan memperoleh pendapatan dengan jumlah yang besar, namun itu tidak menjamin perusahaan membayar dividen yang tinggi kepada pemegang saham. Perusahaan lebih memfokuskan pada pertumbuhan perusahaan maka kebutuhan danapun semakin tinggi yang menyebabkan perusahaan membayar dividen yang rendah kepada pemegang saham. Hasil pengujian ini sejalan dengan penelitian yang dilakukan oleh Hantono et al (2019) menyatakan bahwa sales growth tidak berpengaruh terhadap kebijakan dividen, namun berbeda dengan penelitian Prastika \& Pinem (2016) bahwa sales growth berpengaruh terhadap kebijakan dividen.

\section{SIMPULAN}

Penelitian ini bertujuan untuk mengetahui pengaruh ukuran perusahaan, profitabilitas, leverage, likuiditas dan sales growth terhadap kebijakan dividen. Populasi dalam penelitian ini perusahaan LQ45 yang terdaftar di BEI tahun 2016 -2018. Terdapat 22 perusahaan yang sesuai dengan kriteria penelitian, sehingga jumlah sampel adalah 66 sampel. Penelitian ini menggunakan analisis regresi linier berganda. Berdasarkan hasil penelitian yang telah dilakukan, maka dapat diambil kesimpulan sebagai berikut:

1. Ukuran perusahaan berpengaruh terhadap kebijakan dividen, sehingga Semakin besar ukuran perusahaan maka kebijakan dividen yang dibayarkan kepada pemegang saham pun akan meningkat, sebaliknya jika semakin kecil ukuran perusahaan maka kebijakan dividen yang dibayarkan kepada pemegang saham pun akan semakin menurun.

2. Profitabilitas berpengaruh terhadap kebijakan dividen, sehingga semakin besar jumlah laba yang dihasilkan perusahaan maka jumlah dividen yang dibayarkan kepada pemegang saham pun akan meningkat, sebaliknya jika semakin kecil jumlah laba yang dihasilkan maka jumlah dividen yang dibayarkan kepada pemegang saham pun akan semakin menurun.

3. Leverage berpengaruh terhadap kebijakan dividen, sehingga semakin tinggi leverage perusahaan maka kebijakan dividennya akan semakin rendah, sebaliknya jika semakin rendah leverage perusahaan maka kebijakan dividenya akan semakin tinggi.

4. Likuiditas tidak berpengaruh terhadap kebijakan dividen, sehingga besar kecilnya likuiditas perusahaan tidak mempengaruhi kebijakan dividen.

5. Sales growth tidak berpengaruh terhadap kebijakan dividen, sehingga besar kecilnya tingkat pertumbuhan penjualan perusahaan tidak mempengaruhi kebijakan dividen 
Arifa Nur Azizah et al, Pengaruh Ukuran Perusahaan, Profitabilitas, Leverage, Likuiditas dan Sales Growth terhadap Kebijakan Dividen (Studi Empiris pada Perusahaan LQ45 Yang Terdaftar di Bursa Efek Indonesia Tahun 2016-2018)

\section{DAFTAR PUSTAKA}

Ali, N. Y., Mohamad, Z., \& Baharuddin, N. S. (2018). The Impact Of Ownership Structure On Dividend Policy: Evidence Of Malaysian Listed Firms. Journal of Global Business and Social Entrepreneurship, 4(10), 35-44.

Atmaja, L. S. (2008). Manajemen Keuangan. Yogyakarta: CV Andi Offset.

Ghozali, I. (2012). Aplikasi Analisis Multivariat dengan Program IBM SPSS 20. Semarang: Badan Penerbit Universitas Diponegoro.

Ginting, S. (2018). Pengaruh Likuiditas, Profitabilitas. Dan Leverage Terhadap Kebijakan Deviden Pada Perusahaan LQ45 Yang Terdaftar Di Bursa Efek Indonesia Periode 2012-2016. JWEM STIE MIKROSKIL, 8(2), 195-204.

Hadila, D. M., \& Hapsari, D. W. (2018). Pengaruh Likuiditas, Profitabilitas dan Leveage Terhadap Kebijakan Dividen (Studi Kasus Pada Perusahaan Indeks LQ45 Non-Keuangan yang terdaftar di Bursa Efek Indonesia Periode 2013-2016). EProceeding of Management, 5(3), 3473-2483.

Hanafi, M. M., \& A. H. (2009). Analisis Laporan Keuangan. Yogyakarta: UPP STIM YKPN.

Hantono, Sari, I. R., Felicya, Hartono, A., \& Daeri, M. (2019). Pengaruh Return on Asset, Free Cash Flow, Debt to Equity Ratio, Pertumbuhan Penjualan Terhadap Kebijkan Dividen Pada Perusahaan Property and Real Estate yan Terdaftar di Bursa Efek Indonesia Periode 20142016. Riset \& Jurnal Akuntansi, 3(2), 143-159.

Harahap, S. S. (2016). Analisis Kritis atas Laporan Keuangan. Jakarta: PT Raja Grafindo Persada.

Ikhsan, A. (2009). Akuntansi Manajemen Perusahaan Jasa. Yogyakarta: Graha Ilmu.

Iswara, P. W. (2017). Pengaruh Rasio Likuiditas, Rasio Profitabilitas, Rasio Leverage, Ukuran perusahaan Dan Assets Growth terhadap kebijakan dividen. Jurnal Bisnis \& Teknologi Politeknik NSC Surabaya, 4(1), 33-47.

Jogiyanto. (2013). Metodologi Penelitian Bisnis: Salah Kaprah dan Pengalaman-Pengalaman (Keenam uppl.). Yogyakarta: BPFE.

Kasmir. (2012). Analisis Laporan Keuangan. Jakarta: PT Raja Grafindo Persada.

Lestari, D. (2017). Profitability, Growth Opportunities, Leverage, Ukuran Perusahaan, dan Kebijakan Dividen. Jurnal Riset Manajemen dan Bisnis (JRMB) Fakultas Ekonomi UNIAT, 2, 227 - 240.

Lin, O. C., Thaker, H. M., \& Khaliq, A. (2018). The Determinants of Dividend Payout: Evidence from the Malaysian Property Market. Jurnal Kajian Ekonomi dan Bisnis Islam, 1(1), 27-46.

Lusiana, E., \& Wijoyo, D. S. (2017). Faktor-Faktor Yang Mempengaruhi Kebijakan Dividen Perusahaan Publik Non Keuangan. Jurnal Bisnis Dan Akuntansi, 19(4), 281-291.
Murhadi, W. (2013). Analisis Laporan Keuangan: Proyeksi dan Valuasi Saham. Jakarta: Salemba Empat.

Paramita, S. (2015). Free Cash Flow, Leverage, Besaran dan Siklus Hidup Perusahaan: Bukti Kebijakan Dividen di Indonesia. Jurnal Riset Ekonomi dan Manajemen, 15(1), 169-181.

Prastika, T., \& Pinem, D. B. (2016). Pengaruh Return On Equity, Leverage Dan Sales Growth Terhadap Kebijakan Dividen Pada BEI. Ekonomi Dan Bisnis, 3(2), 134-144.

Priyatno, D. (2013). Analisis korelasi, Regresi, dan Multivariate dengan SPSS. Yogyakarta: Gava Media.

Raharjaputra. (2009). Manajemen Keuangan dan Akuntansi. Jakarta: Salemba Empat.

Rasyid, R. (2018). Pengaruh Kinerja Keuangan Terhadap Kebijakan Dividen (Studi Pada Industri Perbankan Yang Terdaftar Di BEI. Jurnal Muara Ilmu Ekonomi dan Bisnis, 2(1), 188 - 193.

Riyanto, B. (2011). Dasar-dasar Pembelanjaan Perusahaan (4 uppl.). Yogyakarta: BPFE UGM.

Rodoni, A., \& Ali, H. (2010). Manajemen Keuangan (Pertama uppl.). Jakarta: Mitra Wacana Media.

Rudianto. (2012). Pengantar Akuntansi. Jakarta: Erlangga.

Sari, K. A., \& Sudjarni, L. K. (2015). Pengaruh Likuiditas, Leverage, Pertumbuhan Perusahaan, Dan Profitabilitas Terhadap Kebijakan Dividen Pada Perusahaan Manufaktur Di BEI. E-Jurnal Manajemen Unud, 4(10), 3346 -3374.

Soegoto, E. S. (2008). Marketing Research. Jakarta: Elex Media Komputindo.

Sudana, I. M. (2015). Manajemen Keuangan Perusahaan. Jakarta: Erlangga.

Sugiono, A. (2009). Manajemen Keuangan. Jakarta: PT Gramedia Pustaka Utama.

Sugiyono. (2017). Metode Penelitian Kuantitatif, Kualitatif dan $R \& D$. Bandung: CV Alfabeta.

Sutrisno. (2013). Manajemen Keuangan : Teori, Konsep dan Aplikasi. Yogyakarta: Ekonisia.

Tandelilin, E. (2010). Portofolio dan Investasi Teori dan Aplikasi (Pertama uppl.). Yogyakarta: Kanisius.

Vidia, P., \& Darmayanti, N. P. (2016). Pengaruh Penyebaran Kepemilikan, Jaminan Aset, Posisi Kas, Return On Assets Terhadap Kebijakan Dividen. E-Jurnal Manajemen Unud, 5(10), 61166145.

Wijayantini, B., Arif, A., \& Sari, M. I. (2019). Analisis ROA, Current Ratio Dan DER Terhadap Kebijakan Dividen Pada Perusahaan Pembiayaan Di BEI. Jurnal Manajemen Dan Bisnis Indonesia, 5(2), 239 - 246.

www.idx.co.id

Yudiana, I. G., \& Yadnyana, I. K. (2016). Pengaruh Kepemilikan Manajerial, Leverage, Investment Opportunity Set, Profitabilitas Pada Kebijakan 
Arifa Nur Azizah et al, Pengaruh Ukuran Perusahaan, Profitabilitas, Leverage, Likuiditas dan Sales Growth terhadap Kebijakan Dividen (Studi Empiris pada Perusahaan LQ45 Yang Terdaftar di Bursa Efek Indonesia Tahun 2016-2018)

Dividen Perusahaan Manufaktur. E-Jurnal Akuntansi Universitas Udayana, 15(1), 112-141.

Yusuf, R. A. (2019). Factors Influencing Dividend Payout Policy of Firms Listed on the Nigerian Stock Exchange. Advances in Economics and Business, 7(6), 256-265. 